\title{
Change in Elasmobranchs and Other Incidental Species in the Spanish Deepwater Black Hake Trawl Fishery off Mauritania (1992-2001)
}

\author{
L. Fernández, F. Salmerón and A. Ramos \\ Instituto Español de Ocenografía. Centro Oceanográfico de Málaga \\ Puerto Pesquero s/n, E-29640-Fuengirola (Málaga), Spain
}

Fernández, L., F. Salmerón, and A. Ramos. 2005. Change in Elasmobranchs and Other Incidental Species in the Spanish Deepwater Black Hake Trawl Fishery off Mauritania (1992-2001). J. Northw. Atl. Fish. Sci., 35: 325-331. doi:10.2960/J.v35.m534

\begin{abstract}
From 1992 to 2001, by-catch that was landed from the Spanish deepwater trawl fishery for black hake off Mauritania was closely monitored. This is a highly specialised fishery, with two species of black hake (Merluccius senegalensis and Merluccius polli) constituting between 77-99\% of total landings, which have annually averaged 9300 tons over the past two decades. Landings of Sparidae were highest among by-catch species of commercial value, with the large-eye dentex, Dentex macrophthalmus being the most important until 1996, after which the family Lophiidae and others predominated. Next were the Elasmobranchii, including large demersal squalids and several species of rays, although their annual landings fell from 182 tons in 1992 to only 4 tons in 1999, rising to 37 tons in 2001 . The present paper analyses these changes using by-catches retained in the black hake fishery. We believe that the decline could be due to a set of different factors: a change in depths fished, economic reasons and probable over-exploitation of both targeted species and by-catch. Elasmobranchs constituted only $0.1 \%$ of total landings in 1999 , compared to $1.9 \%$ in 1992 , although their contribution to total commercial by-catch was constant. Seasonality was clearly evident, with an absolute and proportional rise in elasmobranch by-catch during warm periods, reaching $75 \%$ of by-catch landings in some months, coinciding with a drop in total by-catch. These seasonal variations could be related to the migratory habits of the fishery's target species, black hake.
\end{abstract}

Key words: black hake, by-catch, elasmobranchs, Mauritania, Spanish fishery, Sparidae

\section{Introduction}

A Spanish wet fish trawler fleet has exploited the Mauritanian deep fishing grounds since the 1950s (Ramos and Fernández, 1995) (Fig. 1). From 1984 to 2001, the landings never exceeded 12000 tons annually, showing an average of 9300 tons. The fishery targets black hake (Merluccius senegalensis Cadenat, 1950 and Merluccius polli Doutre, 1950), with 77-99\% of total landings comprising those two species (Ramos and Fernández, 1992). Although the proportion of incidentally captured species is low, their study represents a significant contribution to knowledge of deep demersal fish structure communities.

Until the mid-1970s, landings of hake species in Mauritanian waters were mainly attributed to Eastern European fleets, but these countries no longer take part in this fishery. The Spanish trawlers also frequented the Mauritanian fishing zone since 1964, under different private or bilateral agreements. The first European Union agreement, which came into force in 1987, was more restrictive, and followed by others signed in 1990, 1993, 1996 and the latest in 2001. At present, the only vessels targeting black hake in the area are three Spanish fleets: fresh trawlers, longliners (since the 1990s) and freezer trawlers (since the 2001 agreement), which usually work under license for the Mauritanian exclusive economic zone (EEZ).

Fishing is prohibited to the south of Cape Timiris $\left(19^{\circ} 21^{\prime} \mathrm{N}\right)$ within an offshore limit of 18 nautical miles measured from the low-tide line, and in the north, inside a line which prevents fishing on the very wide continental shelf of Arguin Bank (Fig. 1). Since the 1996 agreement, the months of September and October are closed to fishing.

The wet fish trawling fleet comprised approximately 19 vessels in 2001, which use of the Baka trawl gear with a $70 \mathrm{~mm}$ mesh size, as specified under the 2001 agreement. Previously, the maximum permitted mesh size was $60 \mathrm{~mm}$. The average vessel characteristics are 228 GRT, $734 \mathrm{hp}, 31 \mathrm{~m}$ length, built in 1983. The fleet's historical minimum was 11 vessels in 1999, when the oldest were retired (Fig. 2). In 2000 and 2001, new, smaller, and less powerful vessels were incorporated, but they were still able to carry out deep fishing on complicated bottoms 


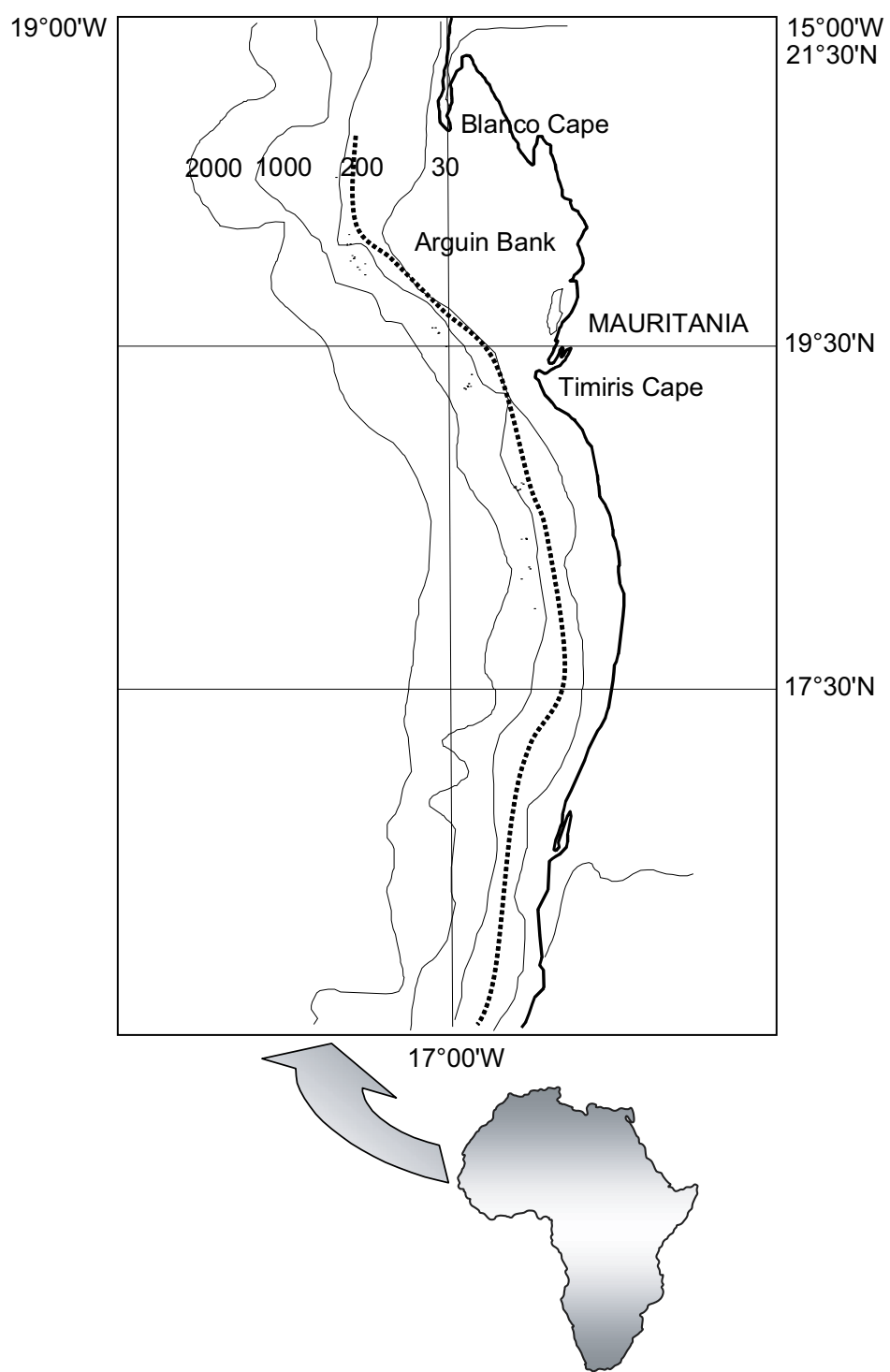

Fig. 1. Location of study area. Under current fishing agreements, the trawl fleet can operate outside of the solid line. Dashed lines show depth contours in $\mathrm{m}$.

featuring rocks and coral formations on the border of the continental shelf and slope, as well as a series of deep trenches and underwater canyons in the northern area (Maigret and Ly, 1986). The fished depth varies from 140-750 m, but the fishery currently tends to work at increasingly greater depths although with some variation according to the seasonal tides, with a recent average depth of up to $710 \mathrm{~m}$ per tide (2003 data from observers on commercial vessels).

Annual catches of black hake averaged 8800 tons during the period 1992-2001, and those of accessory species averaged 492 tons. The total fishing effort has decreased as a result of the different agreements in effect, presenting an annual average of 2500 fishing days. The average length of a fishing expedition dropped to 11 days during the period (Fig. 3), and the quality of the species landed improved. There is no statistical breakdown available on the two black hake species in the commercial catch data.

Scientifically accurate information on catches of both target and by-catch species is important for the management and conservation of stocks. We provide an analysis of 


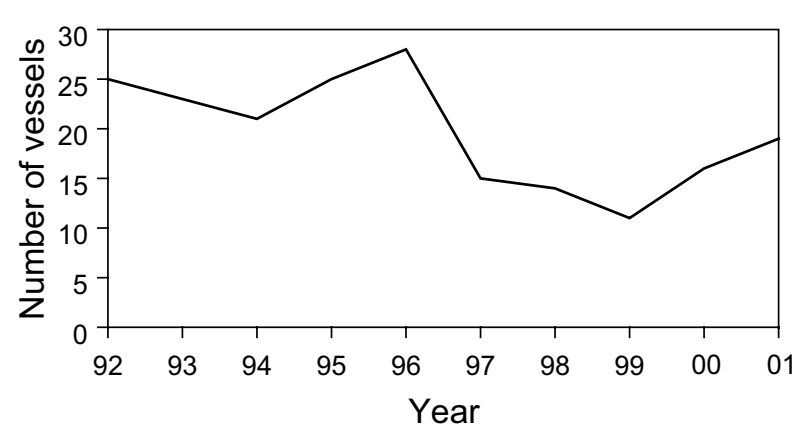

Fig. 2. Number of vessels of the Spanish trawling fleet in the historical data series.

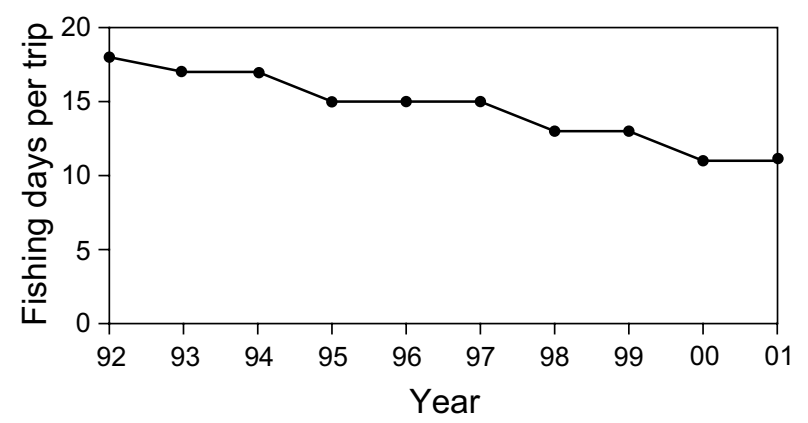

Fig. 3. Average duration of fishing expeditions, in fishing days, of the Spanish trawling fleet during the study period.

changes in the incidentally captured species (the retained by-catch), including landings of demersal sharks and rays (Elasmobranchii), between 1992 and 2001. This paper contributes knowledge to a topic which has been little studied to date, that of the deepwater fisheries and their incidental impact on the elasmobranchs, which is a group of great relevance in fish communities.

\section{Methods}

Landings data from the fishery off Mauritania were collected between 1984 and 2001, by fishing expedition and vessel. The port of Cadiz is the main fish market for black hake, and nearly $100 \%$ of the landings were made there. We also used the daily sales log from each vessel, which provided the best classification of many species. Moreover, the captains' log were useful for analysing the fishing effort by fishing expedition as measured in fishing days, and we also incorporated data on the few landings at another ports.

From 1992, intensive sampling of all landings made it possible to collect individual species or group weight data after each fishing trip. In some cases, the common names used in Cadiz correspond to a perfectly identified single species, but on other occasions, two or more species were listed under the same name, whether they were landed mixed or separately. There were also landings of highly processed species, above all the elasmobranchs, in which specific identification is very difficult or impossible. In these cases, the faunal observations were completed by observers stationed on commercial vessels.

CPUE was obtained by dividing the total landing by specie or species group (kg) by the total effort (fishing days).

\section{Results}

The fleet decreased from 25 vessels in 1992 to 11 in 1999, rising to 19 in 2001 (Fig. 2), over which period the hake and incidental species landings followed the similar trend. The effort dropped from 3595 fishing days at the start to a minimum of 1423 in 1999, then increasing to 2420 fishing days in 2001 (Fig. 4a). Although the hake yields increased, the yield of various species declined to a minimum in 1999 (Fig. 4b).

The number of incidental species or commercial groupings was very high, although the landings of some of these species were negligible. For an overall analysis of by-catch retained, in the present study we divided the species or species groups into larger sets. The most important were the Sparidae (Dentex macrophthalmus (Bloch, 1791), Dentex angolensis Poll and Maul, 1953, Dentex gibbosus (Rafinesque, 1810), Dentex spp., Pagellus spp.) and the Elasmobranchii (main species are listed below). Also recorded were Lophiidae (Lophioides kempi (Norman, 1935) and Lophius vaillanti Regan, 1903) and a wide-ranging group of miscellaneous species, named Others. These included a large number of deepwater species, such as Helicolenus dactylopterus (Delaroche, 1809), Zeus faber Linnaeus, 1758, Zenopsis conchifer (Lowe, 1852), Argyrosomus regius (Asso, 1801), Brotula barbata (Bloch and Schneider, 1801), Scorpaena elongata Cadenat, 1953 and Branchiostegus semifaciatus (Norman, 1931), among the most important.

The accessory species fell from 972 tons (10\% of total landings) in 1992 to 98 tons (1.4\%) in 1999 (Diop et al., $2004)$, rising to 242 tons $(2.6 \%)$ by the end of the period (Fig. 4a). Over the same period, commercial catches of demersal elasmobranchs dropped from 182 tons $(1.9 \%$ of total landings) to only 4 tons $(0.4 \%)$ in 1999 , increasing to 37 tons $(0.4 \%)$ in 2001 (Fig. 5). However, in the by-catch retained, elasmobranch landings were clearly underestimated compared to teleosts, since the elasmobranchs are 

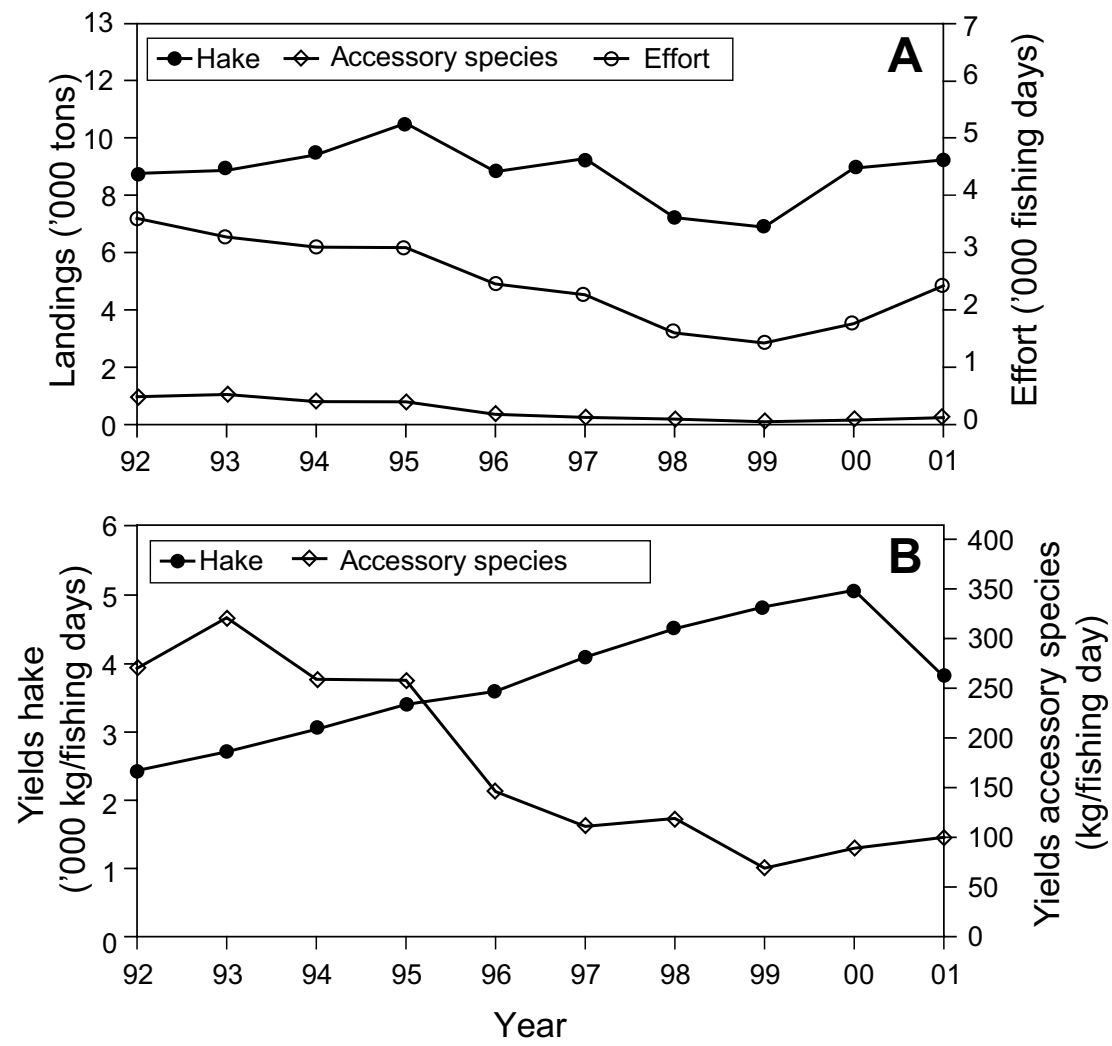

Fig. 4. (A) Landings (tons) and effort (fishing days) and (B) yields (kg/fishing day) in Spanish trawling fleet in deep waters off Mauritania.

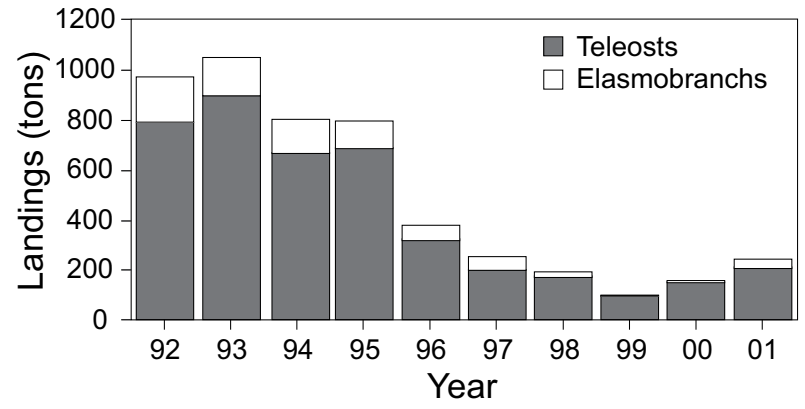

Fig. 5. Commercial by-catch landings of teleosts and elasmobranchs in the Spanish trawling fleet.

subject to greater onboard manipulation; they are normally eviscerated, beheaded, or cut up, with the livers only being retained and recorded in the landing rates, rather than the entire specimen. Within the teleosts, the lophiids were also highly underestimated in the landing statistics, since only the headless fish are weighed for sale. There is also a great deal of discarding within the commercial by-catch, usually due to small size and damaged specimens, but this phenomenon affects all species to some extent, and these data are not incorporated here.
The sparids form the largest component of the accessory species, with the large-eyed dentex, Dentex macrophthalmus being the most important (Ramos and Fernández, 1992; Diop et al., 2004), although its contribution decreased steadily from 1996 onwards, from 50\% (495 tons) of total by-catch landings in 1992 to $12 \%$ (28 tons) in 2001 (Fig. 6).

Elasmobranchs were ranked second until 1997, after which their landings fell and were surpassed by those of the Lophiidae, which made up 5\% (48 tons) of total accessory species landings in 1992 and 31\% (75 tons) in 2001 (Fig. 6). Although the elasmobranch component dropped, their contribution to total commercial by-catch was more constant, with maximum values of $21 \%$ in 1997 and $15 \%$ in 2001, except for 1999 and 2000, when their proportion failed to reach $5 \%$ (Fig. 6).

In 2001, there was an increase in the landings of sparids and elasmobranchs, so that the proportion of lophiids fell, but not the overall commercial landings, which equalled the maximum for the entire historical data series analyses. That year, the duration of the tides dropped by 11 fishing days (Fig. 3), and the marketing system was 


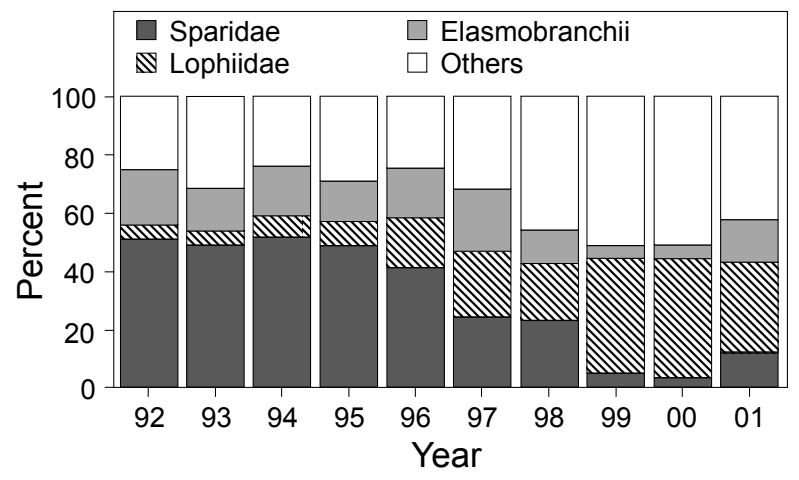

Fig. 6. Main groups of commercial by-catch landings in the Spanish trawling fleet.

changed, improving the presentation of elasmobranchs after their onboard manipulation.

Among the elasmobranchs, the most abundant were the bastina or gelbe, the Spanish commercial name for a wide group of demersal squalids, including Centrophorus granulosus (Bloch and Schneider, 1801), Centrophorus squamosus (Bonnaterre, 1788), Centroscymnus coelolepis Bocage and Capello, 1864, Centroscymnus crepidater Bocage and Capello, 1864, Dalatias licha (Bonnaterre, 1788), Deania profundorum (Smith and Radcliffe, 1912), Deania calcea (Lowe, 1839), Galeus polli Cadenat, 1959, Heptranchias perlo (Bonnaterre, 1788), Oxynotus centrina (Linnaeus, 1758) and Scymnodon ringens Bocage and Capello, 1864, among the most important. The catch of these squalids declined from 158 tons $(87 \%$ of elasmobranch landings) in 1992 to 22 tons (59\%) in 2001, with a minimum of 3.5 tons in 1999 (Fig. 7).

Several members of the family Rajidae are grouped under the Spanish commercial name raya, including Raja straeleni Poll, 1951, Raja miraletus Linnaeus, 1758, Leucoraja leucosticta Stehmann, 1971, Rostroraja alba Lacepède, 1803, as well as others species, all found in deep waters. The landings of rajids in terms of weight fell during our study period (from 18 tons in 1992 to 9 tons in 2001), although less sharply than in the rest of the elasmobranchs, so that proportionally, the landings of this group increased from $10 \%$ in 1992 to $25 \%$ in 2001 . Finally, the school shark or cazón, the Spanish commercial name, Galeorhinus galeus Linnaeus, 1758), which presented the lowest values ( 6 tons in 1992, or 3\% of elasmobranch landings), disappeared completely in 1999 and reappeared in 2001 with a landing of 6 tons (16\% of elasmobranch landings) (Fig. 7).

Our month-by-month analysis shows a clear seasonality, with a rise in the proportion of elasmobranch land-

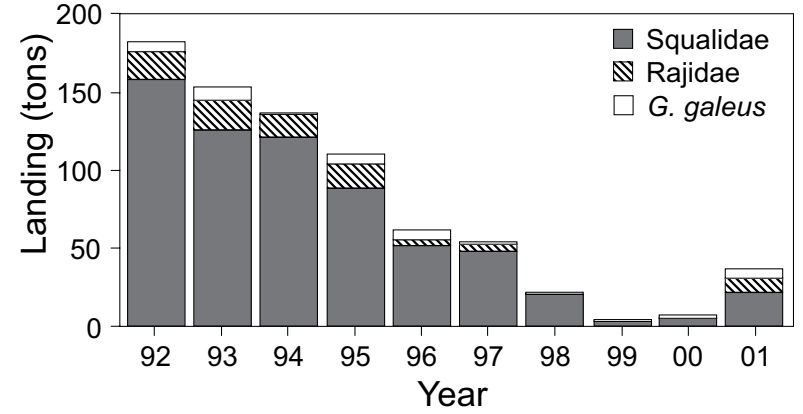

Fig. 7. Main groups of demersal elasmobranchs landings in the Spanish trawling fleet.

ings during warm periods, as high as $75 \%$ of commercial accessory species in some months, coinciding with an increase in overall black hake landings (in other words, a drop in the landed commercial by-catch, especially sparids) (Fig. 8).

\section{Discussion}

The shift in species composition of the landings could be due a various factors. There was a change in the strategy of the fleet, which began to fish in deeper waters after the Mauritanian government imposed a minimum legal length of $30 \mathrm{~cm}$ for black hake in 1996 (Ramos et al., 1998). The heavy sanctions that went into effect for even minor infractions forced the fleet to trawl at greater depths, usually more than $500 \mathrm{~m}$, in an attempt to avoid catching small hake (Overko et al., 1986), which fetched a low price in any case.

Sparids are less abundant at the bottom of the continental slope (Fisher et al., 1981; Whitehead et al., 1986; Boubacar et al., 1999), and consequently caught in lesser quantities there. However, since the elasmobranch species captured are found in deeper waters (Maurin and Bonnet, 1970; Muñoz Chapuli, 1985), it is not known whether the same applies to them. In this case, we think that such a drop could be due, among others, to commercial factors. The wholesale price of elasmobranchs is among the lowest of all the accessory species, and according to sources from the fishery, the value fell sharply during the period under study. This was because there were many large landings being made at the same time. Also the quality of the landed species was low, since the tides were too long in those years for a fresh trawling fleet (Fig. 3). Moreover, the prices of lophiids were very high, and since their capture levels remained constant or even rose slightly, the fleet opted to land these more valuable species.

However, we know from sources in the fishing sector that accessory species catches have fallen sharply dur- 


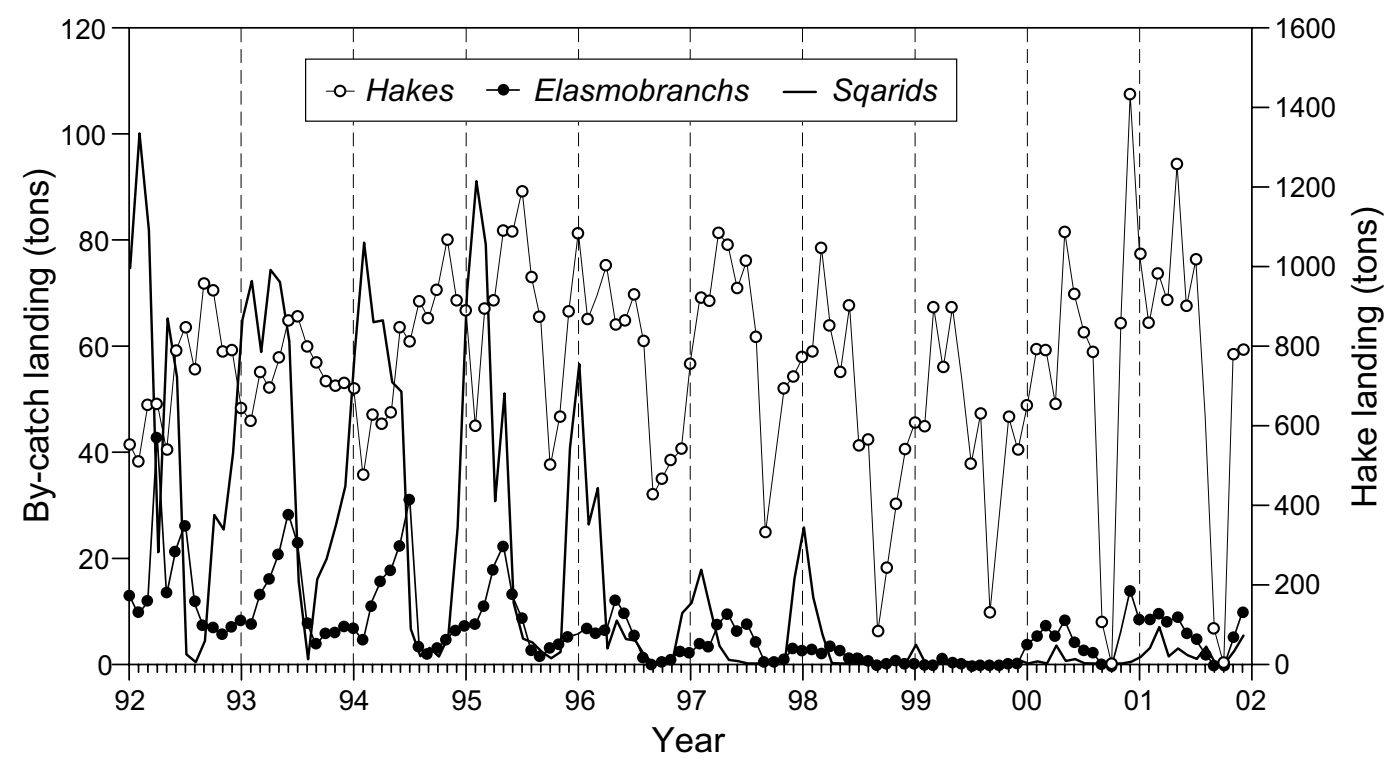

Fig. 8. Black hake and commercial by-catch landings month by month evolution in Spanish trawling fleet.

ing this period, especially those of the elasmobranchs, although the reasons are unclear. Other fleets from Spain and other countries are also fishing in this area with both fresh and freezer vessels focusing on other demersal and semipelagic stocks. Little information is available about them, and therefore we have no way of knowing their impact on the deepwater demersal ecosystem, where the elasmobranchs are the top predators. Indeed, this is a fishing ground which has long suffered from overexploitation by different industrial and semi-industrial fleets, from many countries. This has been illustrated by the Working Group of evaluation of demersal resources of Fishery Committee for the Eastern Central Atlantic (CECAF) area (FAO, 2004).

Although the elasmobranch landing had been falling gradually, it dropped sharply after 1995, when a shift in trawl depth took place. Perhaps the changes we have found regarding elasmobranch by-catch could be attributed to such factors as the loss of economic value of these species, as well as the better price of lophiids, changes in fishing strategy, and an overexploitation of the fisheries in the area. In any case, a variety of factors are necessary to explain the drop in retained by-catch found during the period under study in this fishery, as well as a progressive change in the contribution of each of the three major bycatch groups, with sparids and elasmobranchs tending to decrease, although with a certain recovery in 2001, and the lophiids tending to maintain their position.

The seasonal variations in the proportion of elasmobranch landings could be related to the reproductive or latitudinal migratory habits of the fishery's two primary species, the black hake, which during the warm season move northerly to greater depths (Boukatine, 1986; Caverivière et al., 1986; Overko et al., 1986; Wysokinski, 1986), where more deepwater species are caught, such as elasmobranchs, with a parallel drop in landings of species whose bathymetric distribution is not as deep, such as sparids.

\section{Acknowledgements}

We are grateful to the Professional Association of Fishing Shipowners of the port of Cadiz (known by its Spanish initials, ASEMAR). Their full collaboration and the information they provided have been essential for a better understanding of the fishery. We also express our gratitude to everyone involved in the sampling at the port of Cadiz and the head of its Oceanographic Station, Dr. Ignacio Sobrino.

\section{References}

BOUBACAR, L., D. MIKA, and M. GIRARDIN (eds.). 1999. Guide et Nomenclature Nationale Commerciale des Espèces Marines (Poissons, crustacés et Mollusques) Pêchées en Mauritanie. IEO et CNROP, $216 \mathrm{p}+\mathrm{XI}$ planches, Madrid, España, 1999.

BOUKATINE, P. 1986. Les ressources biologiques du talus continental mauritanien. En: Rapport du Groupe de travail CNROP/FAO/ORSTOM sur le description et évaluation des ressources halieutiques de la ZEE mauritanienne. COPACE/ PACE Sér., 86/37: 147-170. FAO, Roma, Italia.

CAVERIVIÈRE, A., A. THIAM, D. THIAM, and J. L. LÓPEZ ABELLAN. 1986. Rapport de synthese des quatres cam- 
pagnes conjointes hispano-senegalaises de chalutages sur les stocks profonds du Senegal (1982-1984). Arch. Cent. Rech. Oceanogr. Dakar-Thiaroye, 151: 233 p.

DIOP, M., I. SOBRINO, L. FERNÁNDEZ, T. GARCIA, and A. RAMOS. 2004. Evolution des prises accesoires des pêcheries spécialisées crevettière \& merluttière dans les eaux mauritaniennes de 1950 à nos jours. Chavance, P., M. Bâ, D. Gascuel, J. M. Vakily \& D. Pauly (eds.), 2004. Pêcheries maritimes, écosystèmes \& sociétés en Afrique de l'Ouest: Un demi-siècle de changement, Actes du symposium international, Dakar (Sénégal), 24-28 Juin 2002. Bruxelles, Rapports de recherché halieutique A.C.P.-U.E., 15: $139-152$.

FAO. 2004. Rapport du Groupe de travail du COPACE sur l'evaluation des poissons démersaux. Première partie: Nord. COPACE/PACE Séries. No. 04/66/1. Rome, FAO. 2004. 128 p.

FISHER, W., G. BIANCHI, and W. B. SCOTT (eds.). 1981. FAO species identification sheets for fishery purposes. Eastern Central Atlantic Fishing Areas 34, 47 (in part). V. I-VI, FAO, Ottawa.

MAIGRET, J., and B. LY. 1986. Les poissons de mer de mauritanie. Ed. Sci. Nat: 85 p.

MAURIN, C., and M. BONNET. 1970. Poissons des côtes nordouest africaines (Campagnes de la "Thalassa" 1962 et 1968). Rev. Trav. Inst. Pêches Marit., 34(2): 125-170.

MUÑOZ-CHAPULI, R. 1985. Análisis de las capturas de escualos demersales en el Atlántico NE $\left(27^{\circ} \mathrm{N}-37^{\circ} \mathrm{N}\right)$ y mar de Alborán (Mediterraneo occidental). Inv. Pesq., 49(1):
121-136.

OVERKO, S., P. BOUKATINE, and B. LY. 1986. Quelques données sur les merlus de la zone économique mauritanienne. En: Rapport du Premier Groupe de travail spécial sur les pêcheries de merlus et de crevettes profondes dans la zone nord du COPACE. COPACE/PACE Sér., 86/33: 187-201. FAO, Roma, Italia.

RAMOS, A., and L. FERNÁNDEZ. 1992. La pesquería española de arrastre de merluzas negras en aguas mauritanas: análisis de la serie histórica de datos. Instituto Español de Oceanografía, Madrid, Spain. Inf. Téc., 118: 67 p.

1995. Biology and fisheries of North-west African hakes (M. merluccius, M. senegalensis, and M. polli). Alheit and Pitcher (eds.). In: Hake, fisheries, ecology and markets. London, UK. 15: 89-124.

RAMOS, A., L. FERNÁNDEZ, and R. GONZÁLEZ. 1998. The black hake fishery in the Mauritanian EEZ: Analysis of the application of a $30 \mathrm{~cm}$ minimum. Instituto Español de Oceanografía, Madrid, Spain. Inf. Téc., 173: 40 p.

WHITEHEAD, P. J. P., M. L. BAUCHOT, J. C. HUREAU, J. NIELSEN, and E. TORTONESE (eds). 1986. Fishes of the north-eastern Atlantic and the Mediterranean. Paris, UNESCO, vol. I-III, 1473 p.

WYSOKINSKI, A. 1986. Evaluation des stocks de merlus dans les divisions statistiques 34.1.3 et 34.3.1 du COPACE, basée sur des données polonaises (1966-1975). FAO, Rome, En: Rapport du Premier Groupe de travail spécial sur les pêcheries de merlus et de crevettes profondes dans la zone nord du COPACE. COPACE/PACE Sér., 86/33: 72-120. 
